\title{
C-fluxes and C-turnover of a mature mixed beech and pine stand under increasing temperature at ICP Integrated Monitoring site in Neuglobsow (Brandenburg)
}

\author{
H. Schulte-Bisping $\cdot$ F. Beese $\cdot$ H. Dieffenbach-Fries
}

Received: 12 September 2011/Revised: 21 December 2011/Accepted: 16 March 2012/Published online: 4 April 2012

(C) The Author(s) 2012. This article is published with open access at Springerlink.com

\begin{abstract}
Carbon fluxes and C-turnover of a mature mixed forest were assessed over a 5-year period from 2004 to 2008 at the Integrated Monitoring site "Neuglobsow". The mature stand with European beech (Fagus sylvatica L.) and Scots pine (Pinus sylvestris L.) is located in the north-eastern German lowlands (Brandenburg). Soil carbon fluxes of the trenched and non-trenched plots were measured once a week with a closed chamber method to separate heterotrophic and autotrophic respiration. Annual wood increments were continuously measured by dendrometer bands. A strong correlation was found between observed and predicted soil respiration fluxes calculated on the basis of the measured soil temperatures and soil water contents. Carbon sequestration by accumulation in the aboveground biomass accounted for $1.67 \mathrm{Mg} \mathrm{C} \mathrm{ha}{ }^{-1}$ year $^{-1}$. Including the C-sequestration in coarse roots the net primary production (NPP) increased to $2.0 \mathrm{Mg} \mathrm{C}$ per ha and year. Carbon release from soil by apparent heterotrophic respiration was overestimated due to higher soil moisture in the rootless trenching plots. Therefore we adjusted the apparent heterotrophic respiration by means of predicted water contents of the trenched plots, using a SVAT model. Accordingly the apparent heterotrophic
\end{abstract}

Communicated by R. Matyssek.

H. Schulte-Bisping ( $\square$ )

Büsgen-Institute, Soil Science of Temperate Ecosystems, Büsgenweg 2, 37077 Göttingen, Germany

e-mail: hschult1@gwdg.de

F. Beese

Büsgen-Institute, Forest Ecosystems Research Centre,

Büsgenweg 2, 37077 Göttingen, Germany

H. Dieffenbach-Fries

German Federal Environment Agency, Paul-Ehrlich-Str. 29,

63225 Langen, Germany respiration rate was $0.94 \mathrm{Mg} \mathrm{C} \mathrm{ha}^{-1}$ year $^{-1}$ resulting in a net ecosystem production (NEP) of $1.06 \mathrm{Mg} \mathrm{C} \mathrm{ha}^{-1}$ year $^{-1}$. The net $\mathrm{C}$ loss from the soil carbon pool may be caused by higher temperatures, which were increased by $1.5^{\circ} \mathrm{C}$ during the observation period compared to the long-term temperature average (1961-1990). These short-term changes have to be regarded carefully interpreting measured carbon sequestration rates of forest ecosystems in the global carbon cycle.

Keywords Beech pine forest - Wood increment . Carbon pools - Carbon fluxes $\cdot$ Carbon balance

\section{Introduction}

The concentration of $\mathrm{CO}_{2}$ has increased by $38 \%$ from preindustrial $280 \mathrm{ppm}$ in 1750 to $390 \mathrm{ppm}$ in 2010 and presently is increasing at a rate of $2.0 \mathrm{ppm} \mathrm{year}^{-1}$ (WMO 2009; NOOA 2011). The soil carbon pool of $2,500 \mathrm{G}$ tonnes, comprising of $1,550 \mathrm{G}$ tonnes of soil organic carbon (SOC) and $950 \mathrm{G}$ tonnes soil inorganic carbon (Batjes 1996) is 3.3 times the biotic C-pool and about 4.5 times the atmospheric C-pool. These figures clearly demonstrate the importance of soils in the global carbon cycle. In the contemporary global $\mathrm{C}$ budget the terrestrial sinks contribute $10 \%$ (IPCC 2007), and in this context soils play an important role. On the other hand the carbon stored in soils is a dynamic pool, which may quickly react when the environmental conditions are changing. For example preand post-industrial $\mathrm{CO}_{2}$-emissions from anthropogenic land use changes substantially have contributed to the post-glacial increase in atmospheric $\mathrm{CO}_{2}$-concentrations (Lal et al. 1999; Ruddiman 2003, 2005).

Temperature is a key factor that regulates many terrestrial biogeochemical processes, such as soil respiration, $\mathrm{N}$ 
mineralization, nitrification and denitrification, but also fine root dynamic, nutrient uptake, and plant productivity. In a meta-analysis Rustad et al. (2001) have shown that increase in soil temperature in a range of $0.3-6.0^{\circ} \mathrm{C}$ significantly increased the soil respiration rates by $20 \%$, the net $\mathrm{N}$ mineralization rates by $46 \%$ and the plant productivity by $19 \%$. The $95 \%$ confidence intervals were $18-22$, 30-64 and 15-27\% respectively. In their study the response of soil respiration to warming was highest in forest ecosystems.

On the other hand a positive feed back of climate change on the storage and turnover of carbon in terrestrial ecosystems is also observed. For example European forests and grasslands take up approximately $0.305 \mathrm{G}$ tonnes $\mathrm{C}$ per year (CarboEurope-IP 2009). This is about $19 \%$ of the greenhouse gas emissions due to burning of fossil energy resources. Including the $\mathrm{CO}_{2}$ emissions by intensive agriculture and the drainage of peatlands the net annual sink, however, is only $0.274 \mathrm{G}$ tonnes $\mathrm{C}$ or $15 \%$ of the emitted $\mathrm{CO}_{2}$ (Schulze et al. 2009). For German forests a mean annual carbon uptake of 1.53 tonnes $\mathrm{C} \mathrm{ha}^{-1}$ in the standing stock (Dunger et al. 2009) was calculated.

In the last decades we are facing changes in temperature and precipitation patterns in mid-Europe. One important question that has to be answered is whether higher biomass production may lead to an enhanced sequestration of carbon in forest soils or if these changes create a loss of carbon from the carbon pool built up under the previous environmental conditions.

The aim of this study was to determine the net primary production (NPP) and the net ecosystem production (NEP) of a mature pine beech forest ecosystem under actual weather conditions. Therefore the fluxes of carbon were quantified and linked to the variations of soil water contents and soil temperature. Furthermore changes of carbon storage in the aboveground biomass as well as changes of carbon pools in the forest floor and mineral soil were measured. Thus, a proper estimation of the heterotrophic soil respiration and the autotrophic respiration was performed.

\section{Materials and methods}

Study site

The data presented in this paper have been collected from 2004 to 2008 at the ICP Integrated Monitoring (IM) site "Neuglobsow" located in northern Brandenburg, Germany $\left(53^{\circ} 08^{\prime} \mathrm{N}\right.$ and $\left.13^{\circ} 02^{\prime} \mathrm{E}\right)$. The site is set up in 1998 and part of the $14.2 \mathrm{~km}^{2}$ catchment area with the oligotrophic calcareous lake Stechlin in the centre. The catchment was formed by the last Weichselian glaciation. Presently the site is characterized by mixed forests of Scots pine and beech trees undisturbed since 1936. The site has a subcontinental climate with a mean annual temperature of $7.9^{\circ} \mathrm{C}$ and a mean annual precipitation of $658 \mathrm{~mm}$ in the period from 1951 to 1990 (Table 1). Soil type according to the FAO classification is a sandy cambisol with a low soil water capacity (Table 2, Fig. 1).

Biomass and $\mathrm{C}$ pools

The volume of the forest stand was estimated with the tree volume equations from Bergel (1973) using the tree volume applet of Nagel (2007). On the basis of diameter at

Table 1 Stand characteristics of the research area "Neuglobsow"

\begin{tabular}{lllllll}
\hline Tree species & $\begin{array}{l}\text { Age } \\
(2005)\end{array}$ & $\begin{array}{l}\text { Altitude } \\
(\mathrm{m})\end{array}$ & Longitude $\left(^{\circ}\right)$ & Latitude $\left({ }^{\circ}\right)$ & $\begin{array}{l}\text { Mean annual } \\
\text { temperature }\left({ }^{\circ} \mathrm{C}\right)\end{array}$ & $\begin{array}{l}\text { Mean annual } \\
\text { precipitation }(\mathrm{mm})\end{array}$ \\
\hline Scots pine beech & 150 & 65 & 13.02 & 53.08 & 7.9 & 658 \\
& 100 & & & & \\
\hline
\end{tabular}

Table 2 Physical and chemical characteristics of the soil

\begin{tabular}{|c|c|c|c|c|c|c|c|c|c|c|c|c|c|}
\hline $\begin{array}{l}\text { Depth } \\
(\mathrm{cm})\end{array}$ & $\begin{array}{l}\text { Clay } \\
(\%)\end{array}$ & $\begin{array}{l}\text { Silt } \\
(\%)\end{array}$ & $\begin{array}{l}\mathrm{fS} \\
(\%)\end{array}$ & $\begin{array}{l}\mathrm{mS} \\
(\%)\end{array}$ & $\begin{array}{l}\mathrm{gS} \\
(\%)\end{array}$ & $\begin{array}{l}\mathrm{pH} \\
\left(\mathrm{H}_{2} \mathrm{O}\right)\end{array}$ & $\begin{array}{l}\mathrm{C} \\
\left(\mathrm{mg} \mathrm{g}^{-1}\right)\end{array}$ & $\begin{array}{l}\mathrm{N} \\
\left(\mathrm{mg} \mathrm{g}^{-1}\right)\end{array}$ & $\begin{array}{l}\mathrm{C} / \mathrm{N} \\
\left(\mathrm{mmol} \mathrm{kg}^{-1}\right)\end{array}$ & $\begin{array}{l}\mathrm{K} \\
\left(\mathrm{mmol} \mathrm{kg}{ }^{-1}\right)\end{array}$ & $\begin{array}{l}\mathrm{Ca} \\
\left(\mathrm{mmol} \mathrm{kg}^{-1}\right)\end{array}$ & $\begin{array}{l}\mathrm{Mg} \\
(\mathrm{mmol} \\
\left.\mathrm{kg}^{-1}\right)\end{array}$ & $\begin{array}{l}\mathrm{AK}_{\mathrm{e}} \\
(\mathrm{mmol} \\
\left.\mathrm{kg}^{-1}\right)\end{array}$ \\
\hline $0-5$ & 3.4 & 7.9 & 19.7 & 51.2 & 17.9 & 4.1 & 38.2 & 1.9 & 19.7 & 0.8 & 14.3 & 1.9 & 60.2 \\
\hline $5-10$ & 3.3 & 7.8 & 21.4 & 46.1 & 21.3 & 4.3 & 16.9 & 0.9 & 17.9 & 0.4 & 4.1 & 0.6 & 41.2 \\
\hline $10-20$ & 3.3 & 6.9 & 21.3 & 47.2 & 21.2 & 4.4 & 13.1 & 0.8 & 17.2 & 0.3 & 3.7 & 0.5 & 37.3 \\
\hline $20-40$ & 3.6 & 7.9 & 9.4 & 55.0 & 24.1 & 5.0 & 6.1 & 0.4 & 15.9 & 0.3 & 21.8 & 0.9 & 30.6 \\
\hline $40-80$ & 1.2 & 2.5 & 2.8 & 50.8 & 42.7 & 5.2 & 0.4 & 0.1 & 6.1 & 0.2 & 5.7 & 0.5 & 11.9 \\
\hline 80-100 & 1.2 & 1.9 & 3.8 & 48.0 & 45.1 & 6.2 & 1.2 & 0.3 & 4.7 & 0.3 & 54.8 & 1.2 & 60.7 \\
\hline
\end{tabular}




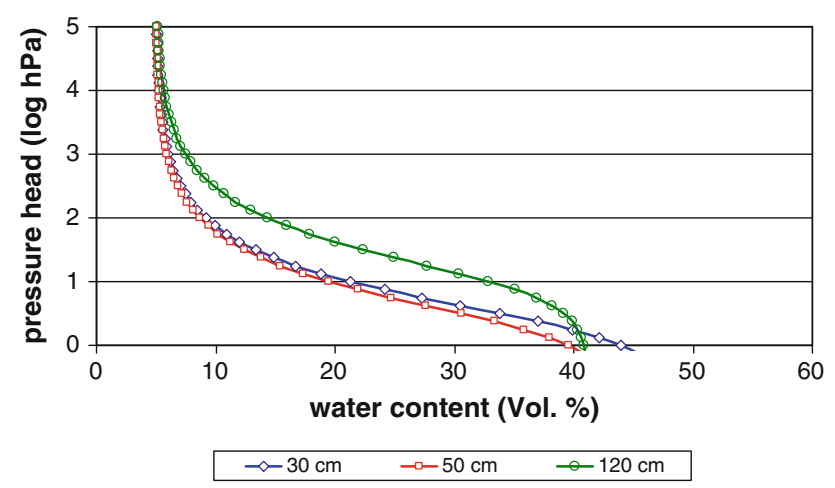

Fig. 1 Water retention curves used in the SVAT module of the ExpertN model

breast height $(\mathrm{DBH})$ and tree height, wood above $7 \mathrm{~cm}$ diameter, that is, merchantable timber volume, was calculated for all trees. These measurements were conducted twice at the beginning and at the end of the study in 2004 and 2008 .

To convert biomass to carbon pool, C pools were calculated from own measurements of carbon content resulting in $53 \% \mathrm{C}$ for pine and $49 \% \mathrm{C}$ for beech trees. Volume expansion factors (VEF) for beech and Scots pine were used to assess total wood volume including twigs and branches using the formula of Pistorius and Zell (2005), Eq. 1:

$\mathrm{VEF}=\frac{B}{D}=\frac{a+b D}{D}$

$B$ : wood volume, $D$ : merchantable timber volume, $a$ and $b$ : constants of timber volume expansion.

Soil carbon pool

Carbon concentrations of the air-dried humus and mineral soil $(<2 \mathrm{~mm})$ samples down to $80 \mathrm{~cm}$ were determined using a HERAEUS-CHN analyser. The soil $\mathrm{C}$ pools for each layer were calculated from the mean carbon concentration, layer thickness and measured bulk densities and stone contents.

Soil $\mathrm{CO}_{2}$ efflux measurements

From the beginning of the monitoring in July 2004 till the end in December 2008 the $\mathrm{CO}_{2}$ fluxes were measured once a week with a closed chamber method. The measurement took place between 10 and 12 a.m. As shown by Brumme and Beese (1992) the fluxes at this time were found representative for the mean daily $\mathrm{CO}_{2}$-fluxes. Six plastic rings $(30 \mathrm{~cm}$ in diameter and $13 \mathrm{~cm}$ height) were placed randomly on the site. The rings were inserted $3 \mathrm{~cm}$ into the soil to prevent lateral gas exchange with the atmosphere. The chambers remained in place over the whole period of time. During measurement the chambers were closed airtight with a lid and a rubber seal. Measurements of carbon dioxide in the headspace were carried out two times with an infrared gas analyser and time intervals of $15-30 \mathrm{~min}$, dependent on the emission rates. The analyser periodically was calibrated with Helium for zero calibration and 1,500 ppm standard gas.

During the measurement the temperature was determined in the chamber and in $5 \mathrm{~cm}$ soil depth. In addition, we installed six trenched plots. Polypropylene tubes with a length of 60 and $30 \mathrm{~cm}$ in diameter were carefully inserted in the soil down to $50 \mathrm{~cm}$ without disturbing the soil structure. These trenched plots were treated in the same way then the other plots.

$\mathrm{CO}_{2}$-C-fluxes $\left(\mathrm{mg} \mathrm{m}^{-2} \mathrm{~h}^{-1}\right)$ were calculated according to Eq. 2:

$F_{\mathrm{CO}_{2}-\mathrm{C}}=\frac{\Delta c}{\Delta t} \times \frac{\left(M \times V_{c}\right)}{M_{v} \times A} \times \frac{P_{a}}{P_{o} \times\left(1+0.00367 \times T_{a}\right)}$

$\Delta c / \Delta t=$ change of the $\mathrm{CO}_{2}-\mathrm{C}$ concentrations per period $\left(\mathrm{ppmv} \mathrm{h}^{-1}\right), M=$ molar mass of $\mathrm{CO}_{2}-\mathrm{C}: 12 \mathrm{~g} \mathrm{~mol}^{-1}$, $M_{v}=$ molar volume of $\mathrm{CO}_{2}-\mathrm{C}: 22.261 \mathrm{~mol}^{-1}, V_{c}=$ volume of installed hood (l), $A=$ area of installed hood $\left(\mathrm{m}^{2}\right)$, $P_{a}=$ air pressure during measurement $(\mathrm{hPa}), P_{o}=$ normal air pressure $(1,013.25 \mathrm{hPa}), T_{a}=$ air temperature during measurement $\left({ }^{\circ} \mathrm{C}\right)$.

Soil respiration was also predicted by an empirical Arrhenius type model based on measured respiration rates, soil water contents and soil temperatures (Eq. 3).

\section{Litterfall}

Twelve collectors with an area of $0.25 \mathrm{~m}^{2}$ each were placed at the site. Sampling of litter was started at the end of 2003. Litterfall was separated into beech leaves, pine needles and one residual fraction comprising fruits of beech, pine cones, bark and twigs. Pooled samples were then prepared for chemical analysis.

Tree growth

The diameters at breast height (dbh) of all standing trees were measured twice in 2004 and 2008. Current annual increment was continuously measured by dendrometer bands made of astralon (UMS, Munich). Dendrometer bands were attached at breast height of 12 trees.

Tree heights were measured with a Blume-Leiss altimeter on a selection of representative individuals with different dbh-classes. The height of all other trees was extrapolated from a regression between tree height and dbh. 
Dissolved organic carbon (DOC)

Dissolved organic carbon was measured in soil solution samples extracted with suction lysimeters in $350 \mathrm{~cm}$ depth during a field campaign from October 2002 until January 2004. Monthly DOC concentrations were used to calculate the mean annual C-flux in seepage waters.

\section{Hydrological measurements}

Open field precipitation was measured daily with five bulk samplers $200 \mathrm{~m}$ beside the experimental site. Fifteen samplers were installed under the canopy and measured weekly. Matric potentials in the soil were measured with three replicates each in a depth of 30,50 and $120 \mathrm{~cm}$. In the same depth water content was observed by means of TDR-sensors and soil temperatures with PT-100 sensors. All these measurements took place in 5 min intervals.

Simulation of soil water content and water fluxes

Soil water contents of the trenched and the control plots were calculated using the SVAT model Expert-N (Priesack 2006; Priesack et al. 2006). In this model water flow in unsaturated soils is simulated by the Richards equation as described in Hydrus-1D (Simunek et al. 1998). The soil hydraulic properties in the model are described by van Genuchten-type soil water retention curves (van Genuchten 1980) and the unsaturated hydraulic conductivities are estimated applying Mualem's approach (Mualem 1976). The van Genuchten parameters of our soil, $\alpha$ and $n$, were derived from TDR and soil water suction measurements using a nonlinear regression model (NLIN-procedure, SAS 1996). The saturated hydraulic conductivity values $\left(K_{\mathrm{S}}\right)$ were taken from tables based on soil texture and bulk density classes (Arbeitskreis Standortskartierung 1996).

Daily potential and actual evapotranspiration values were calculated using the FAO grass reference method according to Penman-Monteith (Allen 2000). Subsequently, distribution of potential evaporation and potential transpiration was achieved by means of the soil coverage (Droogers 2000). Water uptake and actual transpiration of the tree stand were assessed applying the model of Feddes (Feddes et al. 1978). Daily interception was estimated by using an analytical model of rainfall interception (Gash 1979).

Input data for the SVAT model include data on soil properties, climate and vegetation. Basic soil data are depth of soil horizons, soil texture, bulk density and rock content. Daily meteorological data are solar radiation, wind velocity, relative humidity, precipitation and air temperature and were provided by the German Meteorological Service (DWD) from the adjacent station. Vegetation characteristics were the degree of canopy cover and the leaf area index (LAI).

\section{Results}

Soil water budget

The water retention curves and their parameters used in this study are shown in Fig. 1 and Table 3. The plant available water in the main rooting zone $(0-100 \mathrm{~cm})$ amounts to about $60 \mathrm{~mm}$ and is very small. From this finding and the low precipitation and the results of the modelled water budget one can postulate that water will often be a limiting factor for all biotic processes in the system, especially during the vegetation period. The derivation of the curves from field measurements was described in detail in Schulte-Bisping et al. 2005. This also holds for the calibration of the water module used in Expert-N.

The mean of annual precipitation of $586 \mathrm{~mm}$ in the study period (Table 4) lies $72 \mathrm{~mm}$ below the value found in the period of 1951-1990 (Table 1). Air temperature was elevated by $1.5^{\circ}$ compared with the long-term average indicating that the period studied clearly was drier and warmer than the reference period. With a mean potential evapotranspiration of $705 \mathrm{~mm}$ this value lies well above the mean precipitation of $586 \mathrm{~mm}$. The mean transpiration accounted for $352 \mathrm{~mm}$ and interception for $112 \mathrm{~mm}$ per year and differed not very much between the years (Table 4). Drainage, however, showed large differences. This was due to the extremely wet year 2007 with an annual precipitation of $824 \mathrm{~mm}$, which is $238 \mathrm{~mm}$ above the average. Because of the dense canopy soil evaporation is low $(38 \mathrm{~mm})$. This is the reason why the soil in the trenching remains fairly wet over the whole year as shown in Fig. 2, which has consequences with respect to the C-turnover as discussed later. The data of the water budget are in good agreement with the results of other authors studying water budgets of beech and pine forests in this region (Müller 2001; Schulte-Bisping et al. 2005).

In Fig. 2 the modelled water contents in $30 \mathrm{~cm}$ depth with and without root water uptake and the measured water
Table 3 Parameters of water retention curves used in the SVAT model

\begin{tabular}{llllll}
\hline Depth $(\mathrm{cm})$ & $K_{\mathrm{s}}\left(\mathrm{mm} \mathrm{day}^{-1}\right)$ & $\theta_{r}$ vol. $\%$ & $\theta_{\mathrm{s}}$ vol. $\%$ & $\alpha\left(\mathrm{hPa}^{-1}\right)$ & $n$ \\
\hline $0-30$ & 8,600 & 5 & 44 & 0.468 & 1.608 \\
$30-50$ & 5,120 & 5 & 42 & 0.341 & 1.602 \\
$50-120$ & 5,120 & 5 & 40 & 0.182 & 1.580 \\
\hline
\end{tabular}


Table 4 Water fluxes in the 12-year observation period (1998-2009)

\begin{tabular}{|c|c|c|c|c|c|c|c|c|}
\hline Year & Rainfall (mm) & Infiltration $(\mathrm{mm})$ & $\operatorname{ETp}(\mathrm{mm})$ & $\mathrm{Ea}(\mathrm{mm})$ & $\mathrm{Ta}(\mathrm{mm})$ & $\begin{array}{l}\text { Interception } \\
(\mathrm{mm})\end{array}$ & $\begin{array}{l}\text { Drainage } \\
(\mathrm{mm})\end{array}$ & $\begin{array}{l}\text { Water } \\
\text { storage }(\mathrm{mm})\end{array}$ \\
\hline 1998 & 600 & 479 & 623 & 51 & 286 & 117 & 74 & 68 \\
\hline 1999 & 477 & 375 & 700 & 47 & 303 & 102 & 102 & -77 \\
\hline 2000 & 514 & 412 & 623 & 51 & 282 & 102 & 43 & 36 \\
\hline 2001 & 603 & 482 & 600 & 32 & 309 & 121 & 68 & 73 \\
\hline 2002 & 649 & 539 & 628 & 36 & 375 & 111 & 190 & -62 \\
\hline 2003 & 398 & 323 & 726 & 31 & 299 & 75 & 32 & -40 \\
\hline 2004 & 513 & 410 & 636 & 38 & 315 & 103 & 48 & 8 \\
\hline 2005 & 542 & 439 & 647 & 34 & 373 & 103 & 16 & 16 \\
\hline 2006 & 451 & 347 & 760 & 36 & 354 & 104 & 19 & -62 \\
\hline 2007 & 824 & 681 & 750 & 38 & 375 & 144 & 133 & 134 \\
\hline 2008 & 602 & 493 & 732 & 40 & 341 & 108 & 177 & -64 \\
\hline 2009 & 541 & 448 & 725 & 30 & 358 & 93 & 22 & 38 \\
\hline \multicolumn{9}{|c|}{ 2004-2008 } \\
\hline Mean & 586 & 474 & 705 & 37 & 352 & 112 & 79 & 6 \\
\hline SD & 144 & 127 & 59 & 2 & 25 & 18 & 73 & 81 \\
\hline
\end{tabular}

ETp potential evapotranspiration, Ea actual evaporation, $\mathrm{Ta}$ actual transpiration

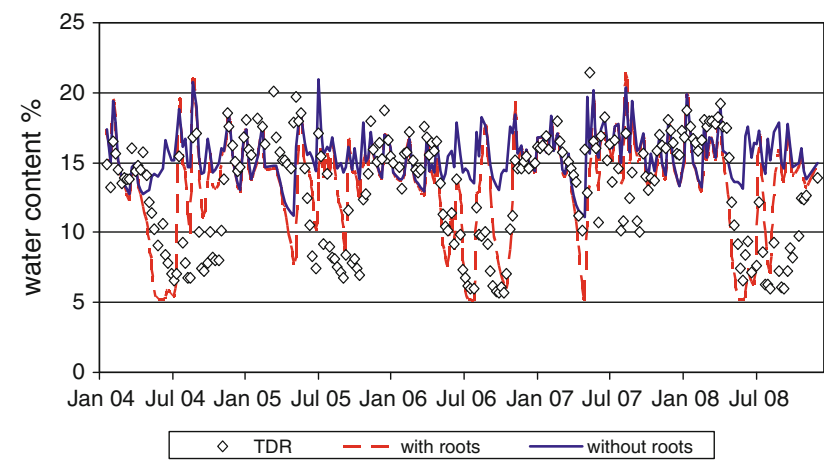

Fig. 2 Simulation of water content in $30 \mathrm{~cm}$ soil depth with (red dashed line) and without transpiration (blue line) compared to TDRobservations. (Color figure online)

contents of the rooted plot are shown. It can be shown that the water content in the trenched plots differ not much over the whole period of time and do not follow the drying periods of the control soil. Therefore the water-induced limitations of the microbial activity occurring in the soil of the control do not take place in the trenched soil. This influence of the apparent heterotrophic respiration in the trenched soil has to be regarded when calculating the apparent heterotrophic and autotrophic respiration of the control.

\section{Carbon pools and fluxes}

Calculations of the volume fractions of beech and pine trees resulted in a total aboveground merchantable timber volume of $529 \mathrm{~m}^{3} \mathrm{ha}^{-1}$ in 2008 (Table 5), beech trees contributed $337 \mathrm{~m}^{3}$ and pine trees $192 \mathrm{~m}^{3}$. Annual timber increment data and volume expansion factors (VEF) were used to calculate the total wood volume and the $\mathrm{C}$-sequestration, both for beech and pine trees. Related to the 5 years studied the mean annual aboveground carbon sequestration rate of this mixed forest was $1.67 \mathrm{Mg} \mathrm{C}$ per hectare. This value is close to the annual aboveground $\mathrm{C}$-sequestration rate of all German forests showing a mean value of $1.53 \mathrm{Mg} \mathrm{ha}^{-1}$ (National Forest Inventory $\left(\mathrm{NFI}^{2}\right.$ ), Dunger et al. 2009). According to data cited in (Ulrich et al. 1981) the ratio of below to aboveground biomass for our stand is about $20 \%$, which corresponds to values described by Schulze et al. (2002). Assuming an increase of the coarse roots according to above-mentioned fraction of $20 \%$, the coarse root increment is $0.33 \mathrm{Mg} \mathrm{C}$ per ha and year, amounting to a total tree biomass increment of $2.0 \mathrm{Mg} \mathrm{C}^{-1}$ year $^{-1}$. This rate is an estimate, because the data of coarse root growth are still very weak.

Litterfall can be regarded as an internal C-flux of the ecosystem. The amount of annual litterfall varied between 5.3 and $7.8 \mathrm{Mg}$ of dry matter (DM) per hectare (Table 6). Annual average of the observed period was $6.43 \pm 1.02$ $\mathrm{Mg} \mathrm{DM} \mathrm{ha}{ }^{-1}$ corresponding to a carbon flux of $3.27 \mathrm{Mg} \mathrm{ha}^{-1}$. Annual differences of leaf and needle biomass were small. However the variation of other compounds was high, mainly due to fructification. Dividing soil $\mathrm{C}$ pools by the mean litter rates results in an apparent turnover time for the forest floor of 7.2 years and for the total soil of 21.5 years, respectively. These figures indicate a biological fairly active soil, which especially holds for the forest floor. 
Table 5 Timber volume, annual increment and C-sequestration (2004-2008)

\begin{tabular}{llllllll}
\hline Species & $\begin{array}{l}\text { Timber } \\
\text { volume } \\
\left(\mathrm{m}^{3} \mathrm{ha}^{-1}\right)\end{array}$ & $\begin{array}{l}\text { Timber } \\
\text { increment } \\
\left(\mathrm{m}^{3} \mathrm{ha}^{-1} \mathrm{year}^{-1}\right)\end{array}$ & $\begin{array}{l}\text { VEF } \\
(\mathrm{a} / \mathrm{b})\end{array}$ & $\begin{array}{l}\text { Wood } \\
\text { volume } \\
\left(\mathrm{m}^{3} \mathrm{ha}^{-1}\right)\end{array}$ & $\begin{array}{l}\text { Wood } \\
\text { density } \\
\left(\mathrm{g} \mathrm{cm}^{-3}\right)\end{array}$ & $\begin{array}{l}\text { C-content } \\
\left(\mathrm{g} \mathrm{g}^{-1}\right)\end{array}$ & $\begin{array}{l}\text { C-sequestration } \\
\left(\mathrm{Mg} \mathrm{ha}^{-1} \mathrm{year}^{-1}\right)\end{array}$ \\
\hline Scots pine & 192 & 1.28 & $0.037 / 1.076$ & 1.41 & 0.42 & 0.53 & 0.32 \\
Beech & 337 & 4.20 & $0.030 / 1.128$ & 4.77 & 0.58 & 0.49 & 1.35 \\
Total & 529 & 5.48 & & 6.18 & & 1.67 \\
\hline
\end{tabular}

a Wood above $7 \mathrm{~cm}$ diameter in 2008

b Volume expansion factor (Pistorius and Zell 2005)

Table 6 Annual litterfall (2004-2008)

\begin{tabular}{lllll}
\hline Year & $\begin{array}{l}\text { Litterfall } \\
\mathrm{Mg} \mathrm{DM} \mathrm{ha}^{-1}\end{array}$ & $\begin{array}{l}\text { Leaves } \\
\mathrm{Mg} \mathrm{DM} \mathrm{ha}^{-1}\end{array}$ & $\begin{array}{l}\text { Needles } \\
\mathrm{Mg} \mathrm{DM} \mathrm{ha}^{-1}\end{array}$ & $\begin{array}{l}\mathrm{Others}^{\mathrm{a}} \\
\mathrm{Mg} \mathrm{DM} \mathrm{ha}^{-1}\end{array}$ \\
\hline 2004 & 7.833 & 2.556 & 1.237 & 4.040 \\
2005 & 5.279 & 2.444 & 1.204 & 1.631 \\
2006 & 5.963 & 2.413 & 1.554 & 1.996 \\
2007 & 7.109 & 2.227 & 1.543 & 3.339 \\
2008 & 5.977 & 2.420 & 1.414 & 2.143 \\
Mean & 6.432 & 2.412 & 1.390 & 2.630 \\
SD & 1.022 & 0.118 & 0.165 & 1.016
\end{tabular}

a Fruits of beech, pine cones, bark and twigs

Table 7 Mean carbon pools and fluxes

\begin{tabular}{llc}
\hline Pools & Year & $\begin{array}{c}\text { Carbon } \\
\left(\mathrm{Mg} \mathrm{ha}^{-1}\right)\end{array}$ \\
\hline $\begin{array}{l}\text { Solid timber } \\
\text { Organic layer }\end{array}$ & 2004 & $\begin{array}{l}154.6 \\
\text { Mineral soil }\end{array}$ \\
\hline Fluxes & 2004 & $\begin{array}{c}23.6 \pm 8.2 \\
46.6 \pm 6.9\end{array}$ \\
\hline Litter & & $\mathrm{Mg} \mathrm{ha}^{-1} \mathrm{year}^{-1}$ \\
Total respiration & $2004-2008$ & $3.27 \pm 0.66$ \\
Heterotrophic respiration & $2004-2008$ & $6.02 \pm 1.04$ \\
Wood sequestration & $2005-2008$ & $4.89 \pm 0.78$ \\
\hline & $2005-2008$ & 1.67 \\
\hline DOC in seapage water & $2002-2004$ & $3.3 \pm 1.2$ \\
\hline
\end{tabular}

The soil carbon pool of the plot amounted to $70.2 \mathrm{Mg} \mathrm{C}$ per hectare (Table 7). About one third is accumulated in the organic layer. Compared to other forest soils in Germany (mean values: $20.7 \mathrm{Mg} \mathrm{C}$ in the forest floor and 87.9 $\mathrm{Mg} \mathrm{C}$ per hectare in the mineral soil) our site exhibits a fairly low pool of carbon stored in the sandy mineral soil.

The measured mean annual soil respiration rate in the period studied was $6.02 \mathrm{Mg} \mathrm{C}$ per hectare, of which $1.13 \mathrm{Mg} \mathrm{C}$ can be attributed to apparent autotrophic respiration and $4.89 \mathrm{Mg}$ to apparent heterotrophic respiration when calculated from the difference between control and trenched plots. The annual decomposition rate from soil organic matter on this basis exceeds the input rate of litter by $1.62 \mathrm{Mg} \mathrm{C} \mathrm{ha}^{-1}$ year $^{-1}$. This net $\mathrm{C}$ loss from soil may be caused by higher temperatures, which as mentioned were increased by $1.5{ }^{\circ} \mathrm{C}$ in this observation period compared to the long-term temperature average (1961-1990). The $\mathrm{C}$ output of just $3.3 \mathrm{~kg} \mathrm{ha}^{-1}$ year $^{-1}$ in form of DOC can be neglected in this balance. As shown later this calculation has to be corrected due to differences in soil water status between the control and the trenched plots.

The mean water use efficiency in the observation period on the basis of transpiration was $2.77 \mathrm{~g}$ dry matter per $\mathrm{kg}$ water and $1.95 \mathrm{~g}$ on the basis of total water used. These low values, Larcher (1994) reports values of 3-5 g dry matter per $\mathrm{kg}$ water for deciduous trees of the temperate zone, can be attributed to the high age of the stand and to water shortage during the vegetation period of most of the years.

One main factor driving biotic decomposition of soil organic carbon is the soil temperature. Figure 3 shows the temperature dependence of the C-emission rates. Especially in the summer and autumn periods with higher soil temperatures large differences in soil $\mathrm{CO}_{2}$ efflux $\left(R_{\mathrm{S}}\right)$ could be observed, mainly caused by different water contents and reduced contribution of the autotrophic respiration to the soil respiration by reduced photosynthetic activity of the trees.

In winter- and springtime up to a level of about $8{ }^{\circ} \mathrm{C}$ the data were less scattered and a nearly linear correlation between temperature and soil respiration was found (Fig. 3). But with increasing temperatures the effect of soil water has a more controlling impact.

\section{Modelling approach}

Soil respiration-defined as the $\mathrm{CO}_{2}$ efflux from the soil surface-originates from the metabolic activity of live roots (autotrophic respiration), microorganisms (bacteria and fungi) and the soil meso- and macrofauna (heterotrophic respiration). The separation of these two processes under field conditions is difficult. Therefore we used the term apparent autotrophic respiration, which according to the experimental set up includes root respiration, fine root turnover and the decomposition of root exudates. Apparent heterotrophic respiration results from the decomposition of 


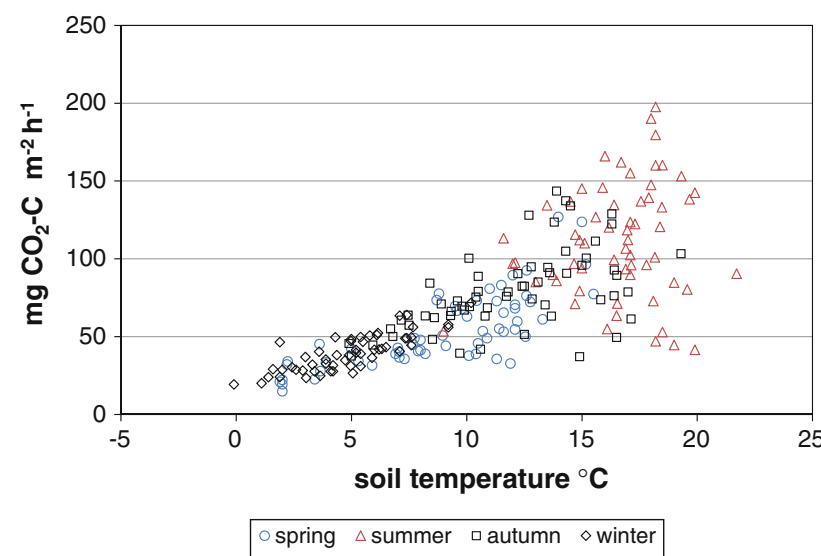

Fig. 3 Soil respiration as a function of soil temperature at a depth of $5 \mathrm{~cm}(n=240)$

soil organic matter. In our approach we used a nonlinear function to predict the soil respiration. This function is based on the equation of Arrhenius (1889) and was extended by the soil matric potential $(\mathrm{hPa})$ as a soil water term (Eq. 3),

$R_{\mathrm{S}}=a \cdot e^{-b /(R \cdot T)} \cdot(1+c \cdot h)$

where $R_{\mathrm{S}}$ is the soil $\mathrm{CO}_{2}$ efflux and Eq. 3 is a nonlinear function of temperature $(T)$ and soil water matric suction (h). $R$ is the ideal gas constant $\left(8.314472 \mathrm{~J} \mathrm{~mol}^{-1} \mathrm{~K}^{-1}\right)$, and $a, b$ and $c$ are free model parameters determined by SAS nlin-regression $(\mathrm{a}=3.65 \mathrm{E} 12, \mathrm{~b}=57.8913, \mathrm{c}=$ $-0.00051)$.

Figure 4 shows the temperature dependence of the soil respiration rates for rates of five different matric potentials obtained by means of Eq. 3. It can clearly be demonstrated that with decreasing matric potentials the increase in soil respiration is reduced and that the decrease increases with rising temperatures. Therefore the soil water status cannot be neglected in modelling the soil respiration.

Based on the measured soil temperature as shown in Fig. 5 and the measured matric potentials in $30 \mathrm{~cm}$ depth

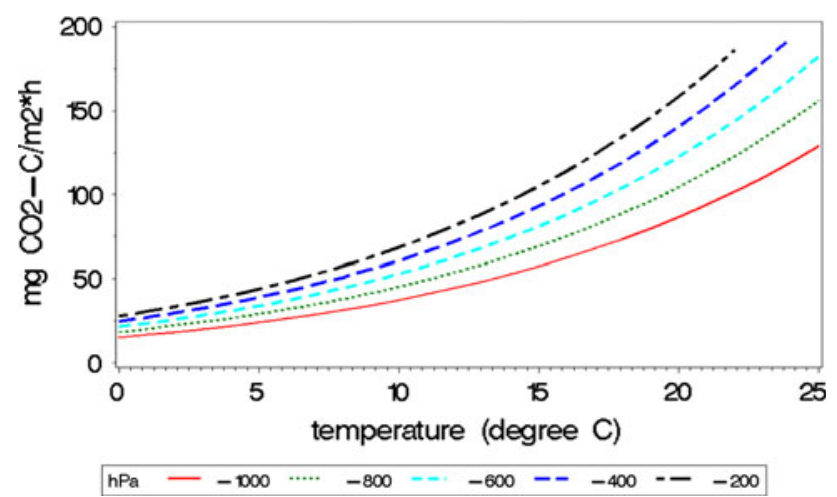

Fig. 4 Modeling soil $\mathrm{CO}_{2}$ efflux rates for five matric potentials as a function of temperature

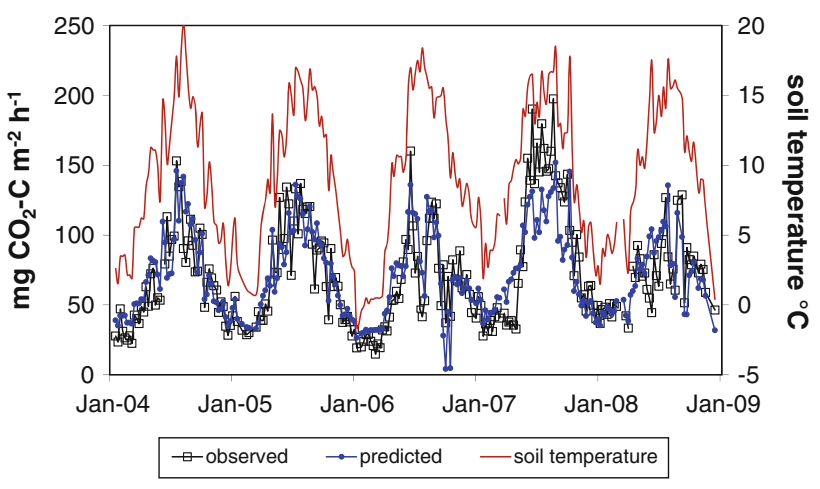

Fig. 5 Observed and predicted soil respiration and soil temperature at a depth of $5 \mathrm{~cm}$

the soil respiration rates for the 5 years period were predicted. In Fig. 5 the observed and predicted rates are shown. This comparison demonstrates that with few exceptions the model describes the soil respiration fairly well. Especially, in the very moist year 2007 the model underestimates the respiration rates. Besides these deviations the annual rates exhibit minor differences as shown in Table 8 . The mean rates over the 5 years period only differ by $27 \mathrm{~kg} \mathrm{C}$ per ha ${ }^{-1}$ year $^{-1}$.

Comparison of total and apparent heterotrophic respiration

In Fig. 6 the relation between the soil respiration and the apparent heterotrophic respiration is shown. The two parameters are strongly correlated and exhibit an $R^{2}$ value of 0.94. In the lower range the relation is quasi linear and it flattens when the soil respiration becomes high indicating that the apparent autotrophic fraction is increasing.

Table 8 Annual $\mathrm{CO}_{2}-\mathrm{C}$ efflux from IM forest site Neuglobsow (bold $=$ observed; italic $=$ predicted $)$

\begin{tabular}{lll}
\hline $\begin{array}{l}\text { Observation } \\
\text { period }\end{array}$ & $\begin{array}{l}\text { Total soil } \\
\text { respiration } \\
\mathrm{kg} \mathrm{ha}^{-1} \mathrm{year}^{-1}\end{array}$ & $\begin{array}{l}\text { Apparent heterotrophic } \\
\text { respiration } \\
\mathrm{kg} \mathrm{ha}^{-1} \mathrm{year}^{-1}\end{array}$ \\
\hline $01.2004-12.2004$ & $\mathbf{5 , 5 6 4}$ & Not implemented \\
& 5,872 & $\mathbf{2 8 3 8}^{\mathbf{a}}$ \\
$01.2005-12.2005$ & $\mathbf{6 , 1 4 8}$ & 2,565 \\
$01.2006-12.2006$ & 5,762 & $\mathbf{4 , 3 0 2}$ \\
& $\mathbf{5 , 1 3 1}$ & 3,132 \\
$01.2007-12.2007$ & 5,544 & $\mathbf{5 , 6 5 5}$ \\
$01.2008-12.2008$ & $\mathbf{7 , 7 5 7}$ & 5,550 \\
& $\mathbf{5 , 5 0 4}$ & $\mathbf{4 , 3 0 9}$ \\
Mean & 5,307 & 3,480 \\
& $\mathbf{6 , 0 2 1}$ & $\mathbf{4 , 8 8 7}$ \\
\hline
\end{tabular}

${ }^{a}$ Observation has started in July 2005 


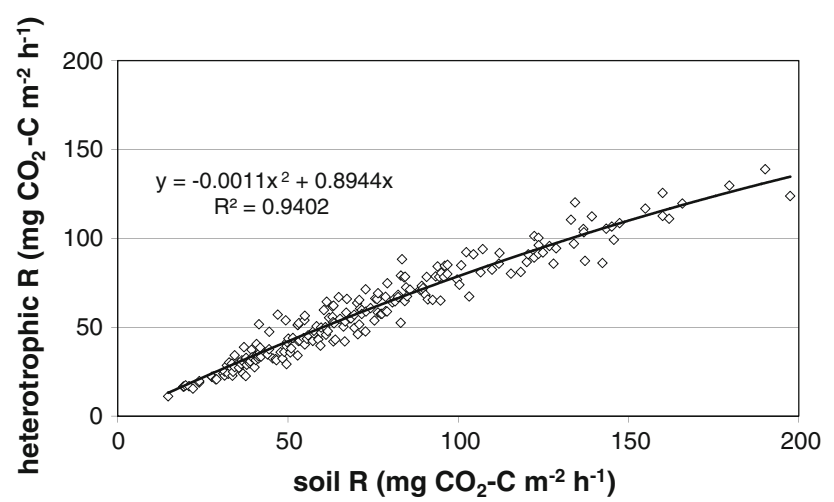

Fig. 6 Correlation between soil and apparent heterotrophic respiration

Observed annual soil respiration rates range from 5.1 $\mathrm{Mg} \mathrm{C}$ in 2006 and $7.7 \mathrm{Mg} \mathrm{C} \mathrm{ha}^{-1}$ year $^{-1}$ in 2007 (Table 8) with a mean value of $6.021 \mathrm{Mg} \mathrm{C} \mathrm{ha}^{-1}$ year $^{-1}$. The very high rate in the extreme moist year 2007 shows that water is a restricting factor in the decomposition process in many years. In average, the deviation between observed and calculated annual rates is very small (27 kg C per ha ${ }^{-1}$ year $^{-1}$ ). In the wet year 2007 the deviation is $766 \mathrm{~kg} \mathrm{C}_{\text {per ha }}{ }^{-1}$ year $^{-1}$ which, however, is compensated by higher rates in the other years. This pattern can be explained by fitting procedure, which is based on the whole data set leading to the best results when the whole period of time is regarded.

The apparent autotrophic respiration that describes the contribution of roots and rhizosphere organisms to the soil $\mathrm{CO}_{2}$-flux can range from 10 to $90 \%$ (Bowden et al. 1993; Hanson et al. 2000). In our observation period from 2005 to 2008 the mean apparent autotrophic respiration of the mixed stand was $1.134 \mathrm{Mg} \mathrm{C} \mathrm{ha}^{-1}$ year $^{-1}$ which is $18.8 \%$ of the total soil respiration. It differed between 16 and $27 \%$. These data are smaller than the results of other authors, which found an apparent autotrophic respiration percentage of 23-26\% in a nearby old-growth beech forest (Jochheim et al. 2007a, b). We have shown that the water content has a high impact on the microbial activity of the soil. We also have shown that the water content in the trenched soil most of the time was higher than in the rooted soil, leading to an overestimation of the apparent heterotrophic respiration. We therefore corrected the measured values with our empirical model by using the calculated water contents of the trenching. This procedure led to a reduction in the apparent heterotrophic respiration by $0.679 \mathrm{Mg} \mathrm{C} \mathrm{ha}{ }^{-1}$ year $^{-1}$. The corrected mean apparent heterotrophic and apparent autotrophic respirations were 4.208 and $1.786 \mathrm{Mg} \mathrm{C}^{-1}$ year $^{-1}$ respectively. The apparent autotrophic respiration was $30 \%$ of the soil respiration and comprises the total root-dependent carbon turnover.

\section{Conclusions}

The results of our 5-year study show that C-fluxes of the mature mixed forest were not balanced. The carbon sequestration was $1.67 \mathrm{Mg} \mathrm{C}^{-1}$ year $^{-1}$ by aboveground biomass accumulation and net loss of carbon from soil organic matter was $0.94 \mathrm{Mg} \mathrm{C}^{-1}$ year $^{-1}$ by apparent heterotrophic respiration resulting in a net ecosystem production (NEP) of $0.7 \mathrm{Mg} \mathrm{C} \mathrm{ha}^{-1}$ year $^{-1}$. This value amounts to $1.06 \mathrm{Mg} \mathrm{C}^{-1}$ year $^{-1}$ when the coarse root growth was included. However, the gains and losses took place in different compartments of the ecosystem. The old trees still accumulate carbon (NPP of $2.0 \mathrm{Mg} \mathrm{C}^{-1}$ year ${ }^{-1}$ ), whereas the soil is losing carbon from a pool build up in former times. This means that for the assessment of the C-sequestration of forest ecosystems the apparent heterotrophic soil respiration has to be regarded. From the environmental factors controlling these processes temperature and soil moisture are most relevant. As shown, these factors have changed in recent years. Compared with the long-term average, the mean annual air temperature was elevated by $1.5^{\circ}$ and the mean annual precipitation was reduced by $72 \mathrm{~mm}$ in the period studied. These deviations from the climatic history of the site have to be regarded, when interpreting the carbon sequestration rates of forest ecosystems. Short-term measurements under conditions which differ from the long-term situation may lead to wrong conclusions.

The simulated soil respiration based on temperature and soil water conditions showed good agreement with the measured values. However in the relative warm and wet summer months of 2007 soil respiration was higher than expected. This indicates that during the vegetation period soil water availability limits biotic activities in most of the years. The gap of $0.94 \mathrm{Mg} \mathrm{C}$ per hectare and year between annual $\mathrm{C}$ input from litter fall and apparent heterotrophic $\mathrm{C}$ respiration results from the correction of the measured apparent respiration of the trenched plots, using the calculated water contents of the SVAT model and our empirical respiration model. Without this correction we would have described the ecosystem as nearly balanced with respect to the carbon budget. The storage in the stand accounted for $1.67 \mathrm{Mg} \mathrm{C} \mathrm{ha}^{-1}$ year $^{-1}$ and the loss from the soil for $1.62 \mathrm{Mg} \mathrm{C}^{-1}$ year $^{-1}$.

In ecosystems where the microbial activity is reduced during the vegetation period due to low water contents, the higher water contents in non-rooted trenched plots lead to an overestimation of the apparent heterotrophic respiration. The study also demonstrates that not only leaves and needles have to be regarded as litter input, but also the other compounds, which in our case amount to $40 \%$ of the litter. 
Based on the assumption that coarse roots have accumulated $0.33 \mathrm{Mg} \mathrm{C} \mathrm{ha}^{-1}$ year $^{-1}$ and the aboveground sink was $1.67 \mathrm{Mg} \mathrm{C} \mathrm{ha}^{-1}$ year $^{-1}$ our results show that this mature mixed forest is still growing and accumulating carbon in the biomass, which even is higher than the weather induced losses from the soil.

Acknowledgments This study was funded by the German Federal Environment Agency (UBA) under grant FKZ 35101040 . We also like to thank Olaf Bath, Christine Casper and Jana Fitzal for their careful field and laboratory work. Data of soil water content were provided by the Leibniz-Institute of Freshwater Ecology and Inland Fisheries (IGB) in Berlin.

Open Access This article is distributed under the terms of the Creative Commons Attribution License which permits any use, distribution, and reproduction in any medium, provided the original author(s) and the source are credited.

\section{References}

Allen RG (2000) Using the FAO-56 dual crop coefficient method over an irrigated region as part of an evapotranspiration intercomparison study. J Hydrol 229:27-41

Arbeitskreis Standortskartierung (1996) Forstliche Standortsaufnahme IHW-Verlag Eching

Arrhenius S (1889) Über die Reaktionsgeschwindigkeit bei der Inversion von Rohrzucker durch Säuren. Z Phys Chem 4:226248

Batjes NH (1996) The total C and N in soils of the world. Env J Soil Sci 47:151-163

Bergel D (1973) Formzahluntersuchungen an Buche, Fichte, europäischer und japanischer Lärche zur Aufstellung neuer Massentafeln. Allg Forst- und Jagdztg 146:117-124

Bowden RD, Castro MS, Melillo JM, Steudler PA, Aber JD (1993) Fluxes of greenhouse gases between soils and the atmosphere in a temperate forest following a simulated hurricane blowdown. Biogeochemistry 21:61-71

Brumme R, Beese F (1992) Effects of liming and nitrogen fertilization on emission of $\mathrm{CO}_{2}$ and $\mathrm{N}_{2} \mathrm{O}$ from a temperate forest. J Geophys Res 97:12851-12858

CarboEurope-IP (2009) An assessment of the European terrestrial carbon balance. In: Schulze ED, Gash J, Freibauer A, Luyssaert S, Ciais P (eds) Druckhaus Gera GmbH

Droogers P (2000) Estimating actual evapo-transpiration using a detailed agro-hydrological model. J Hydrol 229:50-58

Dunger K, Stürmer W, Oehmichen K, Riedel T, Bolte A (2009) Die Inventurstudie, 2008. Der Kohlenstoffspeicher Wald und seine Entwicklung. AFZ Der Wald 64(20):1072-1073

Feddes RA, Kowalik PJ, Zaradny H (1978) Simulation of field water use and crop yield. PUDOC, Wageningen, Simulation Monographs

Gash JHC (1979) An analytical model of rainfall interception by forests. Quart J Roy Meteorol Soc 105:43-55

Hanson PJ, Edwards NT, Garten CT, Andrews JA (2000) Separating root and soil microbial contributions to soil respiration: a review of methods and observations. Biogeochemistry 48:115-146

IPCC, Intergovernmental Panel on Climate Change (2007) Fourth Assessment Report. Working Group III. Report "Mitigation of Climate Change"

Jochheim H, Einert P, Ende H-P, Kallweit R, Lüttschwager D, Schindler U (2007a) Wasser-und Stoffhaushalt eines Buchen-
Altbestandes im Nordostdeutschen Tiefland-Ergebnisse einer 4-jährigen Messperiode. Archiv f Forstwesen Landsch ökol 41:1-14

Jochheim H, Puhlmann M, Augustin J, Wirth S (2007) $\mathrm{CO}_{2^{-}}$ respiration des Bodens und der Wurzeln in einem Buchenwald des nordostdeutschen Tieflands: analyse und Simulation-Mitteilungen der Deutschen Bodenkundlichen Gesellschaft 110(1): 359-360

Lal R, Hassan H, Dumanski J (1999) Desertification control to sequester carbon and mitigate the greenhouse effect. In: Rosenbereg NJ et al (eds) Carbon sequestration in soils. Battelle Press, Columbus

Larcher W (1994) Ökophysiologie der Pflanzen. Ulmer Verlag, Stuttgart

Mualem Y (1976) A new model for predicting the hydraulic conductivity of unsaturated porous media. Water Resour Res $12: 513-522$

Müller J (2001) Ermittlung von Kennwerten des Wasserhaushalts in Kiefern- und Buchenbeständen des nordostdeutschen Tieflands Beitr Forstwirtsch u Landsch ökol 35:14-18

Nagel J (2007) Volumenermittlung stehender Bäume (Online Java Applet). http://www.nw-fva.de/ nagel/forestapplets/volumen/ VolumenApplet.html

NOOA - Earth System Research Laboratory (2011) Trends in atmospheric carbon dioxide. http://wwwesrlnoaagov/gmd/ccgg/trends/

Pistorius T, Zell J (2005) Die Dynamik der Kohlenstoffvorräte in Baden-Württemberg zwischen 1987 und 2002. Veränderungen in der Waldbiomasse und Modellierung der Holzproduktspeicher. AFJZ 176(6/7):103-110

Priesack E (2006) Expert-N Modellbibliothek. Version 3.0. FAMBericht 60, Hieronymus, München

Priesack E, Gayler S, Hartmann HP (2006) The impact of crop growth sub-model choice on simulated water and nitrogen balances. Nutr Cycl Agroecosys 75:1-13

Ruddiman WF (2003) The anthropogenic greenhouse era began thousands of years ago. Clim Change 61:261-293

Ruddiman WF (2005) How did humans first alter global climate? Sci Am 292:429-436

Rustad LE, Campbell JL, Marion GM, Norby RJ, Mitchell MJ, Hartley AE, Cornelissen JHC, Gurevich J, GCTE-News (2001) A meta-analysis of the response of soil respiration, net nitrogen mineralization, and aboveground plant growth to experimental ecosystem warming. Oecologia 126:543-562

SAS Institute (1996) SAS user's guide: statistics. SAS Inst Cary, NC

Schulte-Bisping H, Beese F, Priesack E, Dieffenbach-Fries H (2005) Dynamik des Wasserhaushalts eines Buchen-Kiefern-Altbestandes in Nord-Ostdeutschland (Brandenburg). AFJZ 176(8): $143-152$

Schulze ED, Beck E, Müller-Hohenstein K (2002) Pflanzenökologie. Spektrum Akademischer Verlag, Heidelberg

Schulze ED, Luyssaert S, Ciais P, Freibauer A, Janssens IA et al (2009) Importance of methane and nitrous oxide for Europe's terrestrial greenhouse-gas balance. Nat Geosci 2:842-850. Published online: 22 November 2009 Corrected online: 13 December 2009

Simunek J, Huang K, van Genuchten MT (1998) The HYDRUS code for simulating the one-dimensional movement of water, heat, and multiple solutes in variably-saturated media. Version 60. Research Report No. 144, US Salinity laboratory, Riverside CA

Ulrich B, Benecke P, Harris WT, Khanna PK, Mayer R (1981) Soil processes. In: Reichle DE (ed) Dynamic properties of forest ecosystems, IBP vol 23. Cambridge University Press, Cambridge

van Genuchten MT (1980) A closed-form equation for predicting the hydraulic conductivity of unsaturated soils. Soil Sci Soc Am J 44:892-898

WMO, World Meteorological Organisation (2009) Greenhouse gas bulletin. The state of greenhouse gases in the atmosphere using global observations through 2008. WMO, Geneva 